\title{
INDUSTRIAL IDEALS
}

AcCORDING to newspaper reports the Bishop of Birmingham made an arresting speech at Mürren during the August holidays. His Lordship found his sympathies for the middle classes deepening. When he considered the workers, he is reported to have said: "Owing to the fact that workmen received so much consideration with regard to hours of labour, wages, insurance, amount of work to be done per day, and education for their children, many, instead of developing strength of character, had weakened in their sense of responsibility." Such a pronouncement, from such a source, urges one to look into the developments of the past few decades and to consider some of the policies and ideals that are being pressed upon this country during this period of reconstruction.

The present condition of affairs in our industrial life has been developing since what is known as the Industrial Revolution occurred during the latter half of the eighteenth century. With the invention of the steam-engine and the consequent use of power-driven machinery, the whole current of industrial life was changed. To obtain the full advantages of the new possibility, the large factory employing hundreds, or even thousands, of operatives replaced the old cottage system of manuiacture. The industrial town took the place of the small manufacturing town or village, and as these new towns in many cases sprang up with mushroom-like rapidity at points conveniently situated for supplies of coal and iron, and with facilities for distributing their products, many new and unusual problems evolved. A factory might be established in fairly open country, the operatives needed to live near their work. Thus cottages were built near the factory or mill, without any consideration as to "town-planning" entering the heads of those who were responsible. Straggling streets with every inch of available land under contribution as sites for the dwellings of the rapidly increasing industrial army, led inevitably to the creation of slums and all that slum life entails. There was an extraordinary amount of chaos, socially and industrially.

To the political and industrial leaders of the nation the possibility of producing and accumulating wealth was the outstanding feature of this new epoch in our national life. Seldom has a more interesting or a more difficult position faced any people. The very foundations of life for a growing mass of the population were shifting; nor was the movement so 
gradual that statesmanship could be expected to guide it safely through the early days of the transition. For the transition was far too rapid, and the changes too radical, to permit of the application of any known and tested policy. Here, indeed, was one of the main difficulties of the situation. The world was faced with a new condition of affairs, events happened with an unwonted celerity. There was neither tradition nor experience to appeal to for guidance. What was done was done blindly; there was a series of leaps in the dark. Had dangers been avoided and the ship of industry steered safely through that new and dangerous sea, it would have appeared as though the navigators were inspired with more than human skill. As we know, the quicksands and dangers were not avoided, and the country was awakened to find that material wealth was indeed accumulating to an unheard-of amount, but when those who cared for the moral and physical well-being of our rapidly increasing population began to investigate into social conditions, they were dismayed at the results on the human aspect of this revolution which was making England the envy of all the world. For it became increasingly evident that, side by side with great stores of material wealth and industrial prosperity, there was developing a hideous condition of affairs adversely affecting the great majority of the operatives.

Seldom in human history has a people been face to face with a situation so extraordinarily complicated.

Wealth was increasing, and yet commerce and industry were functioning under great disadvantages. The first desire of the industrial leaders was to break the shackles which threatened to curtail their efforts. Both law and custom had been framed or had developed to regulate a simpler, or at any rate a very different, social condition.

This country had been mainly agricultural, with a few important but comparatively small manufactures. The population, outside London and a few large towns, was fairly evenly spread over the country. Now it was moving into new urban districts-the whole balance of society was disturbed. The capitalist employer was becoming a power in the land; he was taught to buy cheap and sell dear. This policy not only applied to raw materials and manufactured goods, but was unfortunately practised in the hiring of labour. There was no equality of bargaining power between the manufacturer and the individual workman. The law looked with disapproval on any attempt at combination, whether of employer or employed. But it was the latter who suffered most severely from this. Outside one or two important chartered corporations, such as the East India Company and the Bank of England, commerce 
and industry had been carried on by individual traders and master-men operating on a comparatively small scale.

Politically, too, the position was complicated. The American Colonies had successfully asserted their independence, and France, in assisting America, had learnt the dangerous possibilities of resistance to autocratic rule. Europe experienced the effects of the French Revolution, and the last decade of the eighteenth century saw the whole Continent in the meltingpot, industry and commerce neglected, with militarism and war stalking rampant from the English Channel to Russia. For a quarter of a century our quarrels with France entailed costly military operations, and the early years of the new century found this country saddled with a debt of unheard-of dimensions.

Our economic policy was a survival of Tudor and Stuart days. The mercantile system, as it was called, had been a useful scaffolding, necessary for building up a modern worldState. It was evident to thoughtful people that the scaffolding had wellnigh done its work, but statesmen were loath to recommend that a commencement should be made to scrap this scaffolding. Navigation Laws, Corn Laws, Protection, and Labour legislation had been so successful that, to a conservative people like the British, a policy which entailed meddling with these safeguards was naturally viewed with something more than suspicion.

In the economic sphere, however, the work of Adam Smith was working its way, and as to the need for modifying law and custom, Jeremy Bentham played his part. Unfortunately, the section of Adam Smith's book which was most carefully studied and applied was that dealing with the production of wealth. What he had to say about distribution and consumption was almost disregarded. There was a period of "Production run Mad," and the horrors connected with factory conditions became intensified. It may quite relevantly be asked, Who was to blame for the horrible conditions which developed in some of our manufacturing towns? The usual answer to-day is that it was the rapacity of the employers, and from this there has grown up an attitude of mind which has had much to do with the acceptance by the workers of the Marxian doctrine of the inevitableness of class warfare.

If, however, one will but study the conditions in our factories during the early decades of the nineteenth century, a rather different picture is obtained. The desire to grow rich, or to live at ease, was not confined to the employers. There was hardly a section of the community that was not con- 
taminated with the current materialism. It was an almost universally accepted maxim that nothing should be allowed to hinder the work of production. Here was an unlooked-for opportunity for gaining both national and individual wealth, and it was the obvious duty of all to take advantage of it. Cheapness became a god, and cheap labour was held to be a necessary part of cheap production. The fatal habit then formed of studying the wages book for the purpose of keeping wage-rates low became an obsession with many employers, and has had dire consequences not only affecting the relations between capital and labour, but in its full effects placing us at a disadvantage compared with other manufacturing countries. For one at least of our chief competitors has realized that not low wages but low labour cost should be the aim of the progressive business man. Low wages almost universally lead to high labour cost, since they carry in their train the possibility of "ca" canny," and that restriction of output which under modern conditions means a more than corresponding increase in the cost of production. But this is anticipating the story that has to be unfolded.

Just to touch upon the conditions in the factories and their causes, it may be stated that whilst employers used every means to obtain cheap labour, and for this purpose not only cut the rates as far as possible paid to men, but opened their mills to women, girls, and boys -including even children of the tenderest age, other sections of the community played into the employers' hands, either to save responsibility or to make life easier for themselves. Guardians of the Poor saw their opportunity to empty workhouses, more especially of the children, who were indentured on practically any terms so long as the Guardians might be relieved of their charge. And the working population also is not without blame, for early marriages became the rule. The object was to have large families in order that the children might earn at factory or mill the means to enable their parents to live at ease. Nemesis naturally resulted; the wages of the family tended to decrease until the whole sum earned weekly was barely sufficient to keep body and soul together. The employers were to blame? Yes, but let it not be forgotten that the blame was by no means solely theirs. All participated. All were contaminated by the new crude materialism, and in the end all suffered. The excusefor there is an excuse even for these horrors-is that new conditions arose for which there was no precedent. No one had the necessary experience to foretell what would result.

At length a spark of light was kindled, and from that moment things began slowly but surely to mend. About a III. 18 
century ago it began to be evident that all was not well with the country. Men began to realize the almost unnameable conditions existing in certain industrial areas. At first those who investigated felt that so bad was the condition of affairs that Labour would be unable to help itself. Salvation must come from above. The upper and middle classes must reach down the helping hand and lift Labour on to a higher level. This may be looked upon as the commencement of modern Socialism in this country.

Robert Owen, the successful manufacturer, became the apostle of Socialism, and was indirectly the founder of the co-operative movement. He preached and practised that the human agent should be even more carefully considered and treated than the new machinery which was so jealously safeguarded by its owners. Education, high real wages, a higher standard of living, better conditions all round for the worker, became his watchword; he found himself misrepresented and misunderstood. Being of a somewhat fiery disposition, he replied effectively but none too wisely. Church and State regarded him at first with suspicion, then with open dislike. Ultimately he became warped, it is true, but the great benefits he was an instrument in creating are even now only partially recognized.

The elder Peel-the father of our Factory Acts; the Christian Socialists-Maurice, Kingsley, Hughes, and their associates; Lord Shaftesbury and many another honoured name, all worked towards the same end.

Manual labour, however, although living under conditions in many cases difficult for the present generation to realize, was not unable to work for its own salvation. In spite of long working hours and the deadening conditions of daily life, there were men who determined to risk health and life in order to prevent the handing on of unspeakable horrors to future genera tions. Their efforts led to the Trade Union movement. Thus there is the exceedingly interesting picture of two sets of reformers working on different, but somewhat parallel lines, to bring about the much-needed improvement in industrial conditions.

It is perhaps unnecessary here to trace all the developments connected with these movements-their successes and failures are for the most part well known. The successes of the Trade Union movement have enormously outweighed any failuresthe present position of Labour in this country is mainly due to its own initiative and powers of organization. That from time to time it should seem to get on to a wrong track is only to be expected. Solid, steady improvement in conditions of 
work and rates of pay have rewarded the efforts of the real leaders of the working classes.

So far as the other movements are concerned, whilst, superficially considered, Christian Socialism failed, yet in reality it accomplished a very great deal. The most tangible result of the efforts of Maurice and his friends is the Working Men's College, which, after a history of over half a century, still flourishes, and carries on the traditions of its founders. A recent book on the subject blames the Oxford Movement for the failure of the Christian Socialists and the Church generally to influence the workers in more material matters:* "Thanks to it her interests were narrowed down to matters concerning her own constitution and ceremonials, and she ceased to reckon it her duty to care for the wellbeing of those outside her own borders; thanks to it social reform followed Marx and not Maurice, and the masses lost all confidence in institutional religion." Whether this be correct or not, Socialism has tended to follow Marx. Class war has become the slogan of the extremists, and incalculable harm has been done to the healthy development of social and industrial reform.

The combined effect, however, of all the efforts made to create a sane public opinion on industrial matters is best realized by comparing conditions in 1820 with those of 1920 . The history of that century shows that an honest attempt was made, and has been fairly consistently followed, to put things right. The national conscience was awakened, and the determination formed not only to alleviate existing evils, but to prevent their continuance. A century in the history of a country is but a short space of time. It took more than six centuries to perfect our parliamentary institutions, and more than five to perfect our judicial system. It will need time to get nearer to perfection in things industrial.

A century and a half ago the great revolution in things pertaining to industry and commerce began with the invention of the steam-engine. Since then the pace of the transition has been continually increasing. Inventions and discoveries have brought all the world into closer touch. India is nearer to England to-day than were London and Liverpool a century ago. The happenings on the markets in New York or the prospects of the cotton and wheat crops throughout the world are known in London within a few moments of their occurrence. The possibility of eliminating unhealthy speculation, entailing over-production and its inevitable results, unemployment and uncertainty, is within our grasp-indeed, one of the marvels

* Christian Socialism, by C. E. Raven, p. 22. 
of modern business is the lessening of the speculative element in genuine operations. The world is within measurable distance of a more perfect industrial and commercial system. Yet, just as a great social advance becomes possible, the efforts of extremists threaten to destroy the chance. We are asked to disregard the lessons of history at a moment when, not only is the situation ripe for the long-yearned-for evolution, but all the conditions warrant the greatest optimism as to the immediate future.

Consider what the present position is. Just prior to the war industrial unrest had increased to such a point that pessimists seemed justified in foretelling a struggle which might lead to civil war. The position was indeed gloomy, and undoubtedly influenced the leaders of our late enemies in decreeing the war. With the outbreak of hostilities the real soundness of British society became evident: "Armageddon created nothing, though it discovered and rediscovered much. For a time it fused all sorts and conditions of men into one class, and that the nation. It revealed how grand and staunch at heart are the mass of our fellow-countrymen when tried by the touchstone of a grave and simple issue that they can understand."* The first need of to-day is that all shall understand the present position and its possibilities, as they grasped the significance of Germany's action in 1914.

Our industrial system, with all its faults, has one very great merit. Like our Constitution, it is elastic and has proved its capacity for evolution. The history of recent decades shows how that evolution has worked and is still working. Yet at the very moment when all the old causes for suspicion and misunderstanding are being made plain, and the remedy can be applied which within a comparatively short time would launch us on a new era of national prosperity in the true sense of the word, we are called upon to scrap all our advantages and plunge into the unknown ocean of revolution. The choice before this country is evolution or revolution: to put the remaining touches to the work of the men who built up our great heritage, and enter upon an epoch which was to them a dream of the very distant future, or to join the "Reds," turn our backs on the past, and intensify class war, till, as in Russia, the whole fabric of society lies in ruins amidst which the greatest sufferers are those to whom the greatest promises were held out by ambitious adventurers.

Stated briefly, the present position is that the more important sections of our industrial force are organized in Trade Unions and Employers' Associations. Both these need further

* "Manifesto to Trade Unionists," see daily papers August 19, 1921. 
perfecting, but the skeleton of the necessary organization was in being even before the war. During the war period measures had to be taken to minimize the possibility of industrial disputes. To this end the Government set up the Whitley system. Already the results have been arresting. With a wider application of this policy we should have each of our industries provided with permanent representative councils, prepared to consider and settle either misunderstandings which might develop into serious troubles, or possibilities connected with trade developments. There is nothing better calculated to allay suspicion and conduce to smooth working relations than personal contact between the parties or their representatives. Here, then, we have rather more than a beginning towards a better state of affairs.

The workers apparently fear that as a consequence of the new equipment of factories and new prucesses introduced to meet the enormous war demand for manufactured goods, there is the possibility of producing the year's normal demand in a few months. This, they fear, would mean over-production and increased unemployment. There is undoubtedly a haunting dread of this happening. But so long as there remain human wants unsatisfied, it is idle to talk of over-production. The new policy should place industries in the position of working for a known demand, and all the factors required to supply the various markets should be able to take common measures to ensure the absorption of what is produced. With a world impoverished by four years of war, followed by the years of uncertainty, the possible demand for all kinds of goods and services must be very great indeed. It is true that owing to uncertainty and suspicion the actual demand both at home and abroad is at present curtailed. If, however, the markets were assured of regular supplies of goods at satisfactory prices there would soon be a change. Nor can one think of a more certain method for producing this assurance than the confidence resulting from cordial co-operation between all those responsible for the making and marketing of the world's supplies.

It should be remembered that commerce and industry in the twentieth century are not the close preserves of a small group of favoured individuals. For any country to maintain a leading position it is necessary that there be harmonious and complete co-operation between all those whose efforts are required to carry on the work of production and distribution. It is not true to say that manual labour creates all wealth, nor is it, on the other hand, just that those who organize should exploit the operatives. There is a growing interdependence among all the factors. The organizer needs the operatives, and 
the operative is ineffectual without the capable organizer; both fail to attain the best if they ignore the services of the scientist, the inventor, and the various classes of commercial skill. The great need of the moment is to recognize the services that each can supply, and to make an equitable distribution of the wealth created amongst all the necessary factors. This should not prove an impossible task. There is a great amount of information available which, rightly interpreted, would show the relative value of each kind of service rendered. All the factors, moreover, should have free access to the available information, in order that responsibility as well as gains may be fairly shared. If financial risks remain on any one section, that section will expect, and in the long run will get, exceptional gains.

To prevent the suspicion that any one section is being exploited the whole situation must be patent to all who claim a share. Not class welfare, but harmonious co-operation alone can lead to the objective which is, after all, the common aim -a healthy, prosperous, contented population living under conditions leading to what is best physically, intellectually, and morally.

The Whitley policy judiciously combined with our existing system should go a long way towards solving the great industrial problems now confronting this country.

A. W. Kirkaldy.

\section{COMMUNION IN ONE KIND}

THE subject of communicating the faithful at the Eucharist in one kind only is raising considerable interest at the present time. Abstention from the Chalice is sometimes recommended by total abstainers, and more frequently of late by others on grounds of health. And there are certainly a number of persons who, for one reason or another, on their own authority refuse to receive the Sacrament in both kinds. It is, therefore, desirable that the practice should be considered.

\section{I}

A study of the history of the Eucharist shows that in the cases of the sick and of the absent and of infants, Communion in one kind was practised in the early Church. But it is also clear that reservation in both kinds was the custom at least in certain places. Infants were apparently communicated in 